Review

\title{
Experimental Animal Model Systems for Understanding Salivary Secretory Disorders
}

\author{
Ji-Youn Kim ${ }^{1}$, Chang-Hyeon An ${ }^{2}$, Jae-Young Kim ${ }^{3}{ }^{\circledR}$ and Jae-Kwang Jung ${ }^{4, *}$ \\ 1 Department of Dental Hygiene, College of Health Science, Gachon University, \\ Incheon 21936, Korea; hoho6434@gachon.ac.kr \\ 2 Department of Oral and Maxillofacial Radiology, School of Dentistry, IHBR, \\ Kyungpook National University, 2177, Dalgubeol-daero, Jung-gu, Daegu 41940, Korea; chan@knu.ac.kr \\ 3 Department of Biochemistry, School of Dentistry, IHBR, Kyungpook National University, 2177, \\ Dalgubeol-daero, Jung-gu, Daegu 41940, Korea; jykim91@knu.ac.kr \\ 4 Department of Oral Medicine, School of Dentistry, IHBR, Kyungpook National University, 2177, \\ Dalgubeol-daero, Jung-gu, Daegu 41940, Korea \\ * Correspondence: widenmy@knu.ac.kr; Tel.: +82-53-600-7322; Fax: +82-53-426-2195
}

Received: 19 October 2020; Accepted: 5 November 2020; Published: 10 November 2020

\begin{abstract}
Salivary secretory disorders are life-disrupting pathologic conditions with a high prevalence, especially in the geriatric population. Both patients and clinicians frequently feel helpless and get frustrated by the currently available therapeutic strategies, which consist mainly of palliative managements. Accordingly, to unravel the underlying mechanisms and to develop effective and curative strategies, several animal models have been developed and introduced. Experimental findings from these models have contributed to answer biological and biomedical questions. This review aims to provide various methodological considerations used for the examination of pathological fundamentals in salivary disorders using animal models and to summarize the obtained findings. The information provided in this review could provide plausible solutions for overcoming salivary disorders and also suggest purpose-specific experimental animal systems.
\end{abstract}

Keywords: animal experimental model; salivary dysfunction; salivary gland; therapeutic strategies

\section{Introduction}

\subsection{Salivary Gland and Saliva}

The oral cavity is a unique, complex structure that is involved in many functions, including respiration, deglutition, mastication, and pronunciation, all of which are essential for the quality and quantity of life [1]. These physiological functions are accomplished by the highly coordinated involvement of the teeth, tongue, palate, gingiva, and other oral mucosa components [1]. Saliva is the aqueous secretion that lines the entire surface of the oral cavity and originates from the acinar cells of salivary glands, and is considered to play a central role in maintaining the integrity and functions of oral compartments [2]. Saliva consists of approximately $99 \%$ water and a variety of components including electrolytes, glycoprotein, proteins represented by enzymes, immunoglobulins, and antimicrobial factors, which contribute to the diversity of salivary properties and functions for both oral and general health $[2,3]$. Salivary glands consist of three pairs of major glands (parotids, submandibulars, and sublinguals), which are located outside the mouth, and a number of minor glands located inside the mouth. Major salivary glands contain three main cell types: acinar cells, ductal cells, and myoepithelial cells [4]. In addition, the connective tissue forms a capsule around the gland and extends into it, dividing groups of secretory units and ducts into lobes and lobules. Blood vessels, lymphatic vessels, and nerves are also present within the capsule for supplying the 
gland [5]. The functional unit of a salivary gland is called the acini. Acini are composed of epithelial secretory serous and mucous cells and are responsible for the production of saliva. The serous or mucous cells along with myoepithelial cells are arranged in an acinus or acini with a roughly spherical or tubular shape and a central lumen [5]. Myoepithelial cells wrap around the acini and intercalated ducts with four to eight processes, rhythmically contracting to squeeze saliva from the acinar units upon stimulation by nerves, through the duct system, and into the oral cavity [4]. Pathological alterations in secretory elements (acinar, duct, myoepithelial, and nerve) can cause salivary secretory disorders, leading to various life-disrupting pathological events [6].

\subsection{Salivary Secretory Disorders and Animal Models}

Salivary secretory disorders can be caused by a wide range of oral and systemic conditions, leading to histocellular disturbances in the salivary gland and, consequently, a quantitative and qualitative decline in saliva [7]. These conditions include the prolonged use of systemic medications, the application of radiation or radioisotope treatment, glandular pathologies such as sialadenitis and sialolithiasis, and systemic diseases, such as diabetes and Sjögren's syndrome [8]. Although the therapeutic target should be centered on histopathologic impairment the underlying salivary dysfunction, almost all clinical therapies are helpful for only temporary symptomatic relief without recovery of histofunction [8]. Accordingly, a number of experimental animal models have been developed to clarify the detailed mechanisms underlying the initiation, progression, and recovery in salivary pathologies [9-14]. These models were created by the application of excessive irradiation, radioisotope, ductal ligation, inflammogens, mechanical injury, medications, and genetic modifications [6,15-20]. A radiation and radioisotope model was developed to reproduce the hyposalivation induced by head and neck cancer therapy. The ductal ligation model aimed to mimic the obstructive sialadenitis and sialithiasis-induced sialopathy. A model of inflammation, mechanical injury, and systemic disease/medications was devised to correspond to Sjögren's syndrome and virus/bacterial sialadenitis, traumatic injury-induced sialopathy, and sialopathic alterations under diabetes, renal disease, hypertension, and/or their therapeutic medications. Although previous studies using various applications of experimental animal models have reported a variety of histocellular findings, the analytical comprehension of previous methodologies and findings could be advantageous for both clinicians and researchers to help facilitate preclinical research for the future development of new therapeutic strategies.

\subsection{Objectives}

The purpose of this article is to provide a methodological summary to improve future experimental protocols and consolidate previous histofunctional findings underlying salivary glandular impairment and recovery. This review focused exclusively on the practical considerations regarding various experimental procedures applied in animal studies.

\section{Methods}

We searched for available studies in English using the PubMed database (up to April 2020) and references for other literature. The search was performed in PubMed repeatedly using the keywords "salivary gland", "radiation" (or "irradiation"), "ligation" (or "obstruction"), "animal" (or "animal model"), and other related words. Secondary searches were performed among the references cited in the articles initially found. The collected studies were carefully reviewed from the methodological and histomolecular points of view.

\section{Results}

\subsection{Experimental Animal Models}

Animal models were used to study radiation-induced salivary gland dysfunction, radioactive iodine-induced sialadenitis, acute/chronic obstructive sialadenitis, bacterial sialadenitis, sialithiasis, 
diabetes-induced salivary dysfunction, and Sjögren's syndrome. Various animal species, including rat, mouse, cats, pigs, monkeys, sheep, and others, have been used as models of salivary secretory disorders [21-23]. Previous studies have confirmed that experimental models reproduced similar histopathological alterations in salivary glands, with some variations between species and individuals; moreover, these alterations were closely related to salivary dysfunction $[9,23,24]$. Table 1 outlines the previously used animal models and their mimicking salivary diseases or disorders in humans.

Table 1. Summary of the experimental animal models mimicking sialopathies.

\begin{tabular}{ccc}
\hline Type of Animal Model & Experimental Method & Aimed Pathologic Diseases/Disorders \\
\hline Radiation model & $\begin{array}{c}\text { Irradiation using experimental radiation } \\
\text { equipment }[9,20]\end{array}$ & Radiation-induced sialopathy/sialadenitis \\
\hline Radioisotope model & Administration of radioiodine [13,19] & Radioactive iodine-induced sialadenitis \\
\hline $\begin{array}{c}\text { Ductal obstruction (ligation) } \\
\text { model }\end{array}$ & $\begin{array}{c}\text { Obstruction of salivary duct using } \\
\text { surgical suture or aneurysm clip [11,17] }\end{array}$ & $\begin{array}{c}\text { Obstructive sialadenitis, } \\
\text { sialithiasis-induced sialopathy }\end{array}$ \\
\hline Inflammation model & $\begin{array}{c}\text { Application of autoimmune disease } \\
\text { animal models or inflammogens [14,15] }\end{array}$ & Sjögren's syndrome, bacterial sialadenitis \\
\hline Mechanical injury & $\begin{array}{c}\text { Direct induction of tissue damage } \\
\text { mainly using biopsy punch [10,16] }\end{array}$ & Traumatic injury-induced sialopathy \\
\hline Systemic diseases/medications & $\begin{array}{c}\text { Application of systemic disease animal } \\
\text { models and/or their therapeutic } \\
\text { medications [12,18,25] }\end{array}$ & $\begin{array}{c}\text { Sialopathic alterations under diabetes, } \\
\text { renal disease, hypertension, and/or their } \\
\text { therapeutic medications }\end{array}$ \\
\hline
\end{tabular}

Dental clinicians are more likely to encounter patients with several sialopathies, such as medication-induced dysfunctions, radiation-induced sialopathy, obstructive or inflammatory siadenitis, and sialithiasis $[9,26]$. However, upon careful literature review, it was found that animal models for medication-induced dysfunctions were not fully established. Therefore, the remainder of this article will focus solely on the radiation model and ductal obstruction model (Figure 1).

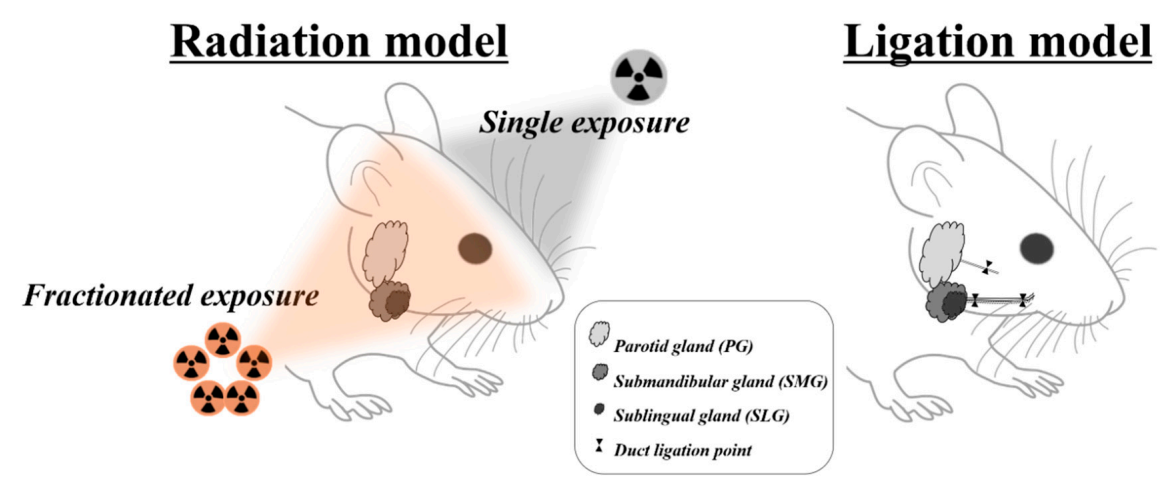

Figure 1. Overview of animal models mimicking radiotherapy- and duct obstruction-induced salivary gland damage.

\subsection{Radiation Model}

\subsubsection{Experimental protocols}

Various malignant tumors occur around the head and neck areas. In 2018, more than 710,000 patients suffered from these tumors, with a corresponding 350,000 deaths worldwide [27]. Although radiotherapy is considered to be one of the main anticancer therapies for head and neck cancers, radiation-induced hyposalivation is also one of most common complications, mainly resulting from the destruction of salivary tissues with their high biological susceptibility to radiation $[27,28]$. Copious studies using a radiation model have been performed, with a variety of radiation dosages administered over different species [22,28-32]. The irradiation procedure could be divided into 
single-dose and fractionated irradiation according to its schedules. In contrast to a single high irradiation dose, fractionated irradiation is defined as the application of radiation dosage fractionated into far smaller doses over several weeks [28]. Fractionated irradiations are considered more similar to radiotherapy procedures, with typical time courses of 6 weeks $[28,33]$. According to the collected literature, mice, rat, minipig, monkey, and rabbit are mainly used for radiation models. Among these, most animal studies include mice and rats. In the mice irradiation model, a single dose of 2-18 Gy or a fractionated dose of $28 \mathrm{~Gy}(5.6 \mathrm{~Gy} \times 5$ days) is performed. In the rat irradiation model, 7.5-20 Gy is used as a single dose, and a total of 20-75 Gy $(4,6,7,8,9,15$ Gy $\times 5$ days $)$ is used as a fractionated dose. The irradiation models using minipig, monkey, and rabbit were produced mainly through a fractionated irradiation of 37.5-70 Gy.

\subsubsection{Main Findings}

Previous studies have reported that histological alterations such as acinar loss are intimately related to radiation dose [29,34-36]. However, it should be considered that irradiation with a single high dose might significantly shorten the life span of the experimental animals [36]. Previous research showed that irradiated salivary glands were characterized histologically with parenchymal loss, acinar atrophy and interstitial fibrosis, duct proliferation, and dilated intercalated and striated duct $[6,9,23]$. A previous study reported in the rat indicated that a single exposure of $15 \mathrm{~Gy}$ induced considerable reductions in the weights of the parotid and submandibular/sublingual glands (by $36 \%$ and $24 \%$, respectively) as well as salivary flows of the parotid and submandibular/sublingual glands (by $74 \%$ and $46 \%$, respectively) [37]. However, findings regarding the relative radiosensitivity of the salivary glands were conflicting [22,23,37]. Although DNA was considered to be the main critical target of radiodestructive effects, several studies were performed to determine the detailed pathologies of apoptosis in salivary acinar cells. These researchers reported that p53 could be a key molecule in the regulation of radiosensitivity via the probable involvement of DNA damage repair, cell cycle arrest, and apoptosis [28]. Noticeably, it was furthermore revealed that radiation exposure induced no apoptosis in knockout mice with $\mathrm{p} 53^{-/-}$as determined by immunohistochemistry of caspase-3 [29]. These findings demonstrated that post-irradiation apoptosis in the salivary gland could be mediated by $\mathrm{p} 53$. In addition, other study reported that post-irradiation apoptosis was suppressed by greater than $60 \%$ in the parotid glands of $\mathrm{PKC}^{-1-}$ mice when compared with wild-type mice [38]. This finding indicates that PKC $\delta$ is required for the efficient induction of post-radiation apoptosis in salivary epithelial cells.

However, recent studies have indicated that the sharp and persistent decline in salivation flow cannot be fully explained by only the loss of acinar cells after irradiation $[28,39,40]$. In addition to apoptosis, the down-regulation of acuaporin 5 (AQP5) is considered to be a contributing mechanism of the induction of post-irradiation hyposalivation. It was reported that the expression of AQP5 was down-regulated in the salivary glands with decreased salivation on days three and 30 after irradiation [41]. Other studies have described that the disturbance in the calcium signaling pathway through TRPM2 might underlie the post-irradiation dysfunction in the salivary gland [40,42]. A previous study found that although wild-type mice exhibited prolonged hyposalivation after radiation, the duration of recovery from hypofunction was facilitated in TRPM2-/- mice [43]. Another study revealed that, after irradiation, TRPM2 $2^{-/}$mice displayed only transient loss of STIM1 and Store-operated Ca2+ entry (SOCE) along with transient hyposalivation and, moreover, gene therapy to express STIM1 increased the salivary flow and SOCE [40]. Collectively, recent studies showed that irradiation of the salivary gland was accompanied by extensive deterioration including decreased AQP5 expression, parasympathetic innervation (GFR $\alpha 2$ and AchE expression), regeneration potentials (Shh and Ptch expression), salivary trophic factor levels (brain-derived neurotrophic factor and neurturin), and stem cell expression (Sca-1) [44].

In addition to acinar cells, impairment of nonparenchymal tissues such as the parasympathetic nerve and microvessels was reported as an additional mechanism of radiation injury [6,44,45]. 
These studies reported that parasympathetic dysfunction and vascular dilation were observed as part of late postradiation effects [6,46].

Recent studies have shown a distinctive regeneration pattern in the salivary gland after irradiation, as compared with homeostatic regeneration under normal conditions [6,20]. Under normal conditions, differentiated acinar cells can be maintained and regenerated through self-duplication of acinar progenitors in a lineage-restricted pattern $[47,48]$. Meanwhile, under normal conditions, the K14-expressing duct cells are known to contribute to the formation and maintenance of ductal structures but not acinar structures [49]. However, it was recently revealed that, after irradiation, the ductal cells as well as acinar cells contribute to the generation and repair of acinar cells [20]. This finding suggests that cellular plasticity would be involved in the restoration of the salivary gland after severe cellular damage, such as irradiation [20] (Table 2).

\subsection{Ductal Obstruction Model}

\subsubsection{Experimental Protocols}

An animal model with experimental ductal obstruction has been used to mimic sialopathies via obstructive sialadenitis and/or sialithiasis. According to the collected studies, mice, rat, cat, and rabbit were primarily used for the production of ductal obstruction models. Ductal obstruction in rodents was applied mainly in submandibular and less in the parotid gland. This might be because the submandibular gland is the largest and easiest salivary gland to identify grossly [74]. The obstructive period varied considerably from $24 \mathrm{~h}$ to one year, which could be suitable for reproducing acute and chronic sialopathies, respectively $[21,24,75-77]$. According to the study design, the removal of obstructers such as silk or clip was often performed to reproduce the repair stage by restoring the ductal passage [75,78-80]. Ductal obstruction was mainly achieved by ductal ligation with surgical silk or ductal clipping with an aneurysm clip. More recently, the ductal clipping method was predominantly used because the clipping procedure is a more simple and less traumatic method during both operations of obstruction and, especially, later removal. In addition, to avoid fibrosis of the ducts by minimizing irreversible ductal damage, studies attempted to insert a small plastic tube at the neck or the joint of the clip [11,81]. Although many studies have used the unligated contralateral glands as controls, a previous study used the corresponding gland of an unoperated, naive animal [81]. The possibility was considered that, when the unilateral gland was obstructed, the compensatory hyperplasia would occur in the unligated, contralateral gland [82].

\subsubsection{Main Findings}

Previous studies revealed a marked decrease (75\%) in the weight of the salivary gland after experimental obstruction [17,83-85]. The dramatic atrophy could make it more difficult to identify the obstructed gland and then to stitch out the tightly knotted silk without causing any ductal damage [85]. Therefore, the use of a metal clip appears to be more advantageous in terms of convenience and safety. In the past, rats were more frequently used as experimental animals for clipping than mice, probably because of the surgical feasibility, whereas experimental mice were considered to have unique advantages of well-identified genetic backgrounds over other animals. However, since the introduction of the mini-clip, the mouse has been more actively used by overcoming the limitation of size [78,84]. The location of the experimental obstruction is grossly divided into the proximal ductal portion through the extraoral or cervical approach and the distal ductal portion through the intraoral approach $[81,85]$. On the proximal portion of the salivary duct, the main duct runs together with the parasympathetic nerve and blood vessel by connective sheath. Distal obstruction is usually determined to minimize any compounding effect by possible ligation or clipping of other structures, such as the parasympathetic nerve and the supplying blood vessel $[11,79,86]$ (Figure 1). However, it is not easy to select the distal obstruction in mouse because of the restricted animal size and surgical accessibility. Although it might 
be possible to avoid the ligation of surrounding blood vessels and nerves under surgical stereoscope, high surgical skill still seems to be needed to perform the surgical procedure in the mouse [85].

Table 2. Irradiation protocols used in previous studies.

\begin{tabular}{|c|c|c|c|c|c|}
\hline Animal & Target Gland & Dose (Total) & Fraction No. & F/U Period & Ref. \\
\hline \multirow{12}{*}{ Mice } & \multirow[b]{2}{*}{ PG } & 2, 5 Gy & Single & $1,2,3,4,30$ days & [29] \\
\hline & & 5 Gy & Single & $\begin{array}{c}5,10,15,30 \mathrm{~min}, 1,2,4 \mathrm{~h} \\
30,60 \text { days } \\
4,5,7,30 \text { days } \\
8,24 \mathrm{~h} \\
1,2,3 \text { days }\end{array}$ & $\begin{array}{l}{[50]} \\
{[51]} \\
{[52]} \\
{[53]} \\
{[54]}\end{array}$ \\
\hline & \multirow{5}{*}{ SMG } & 10 Gy & Single (5 Gy per side) & $3,7,14,30$ days & [55] \\
\hline & & $12 \mathrm{~Gy}$ & Single & $4,8,12$ weeks & [56] \\
\hline & & 13 Gy/28 Gy & Single/fraction $(5.6$ Gy $\times 5$ days $)$ & $48,72 \mathrm{~h}, 2,8$ weeks & [57] \\
\hline & & 15 Gy & Single & $\begin{array}{c}8,24 \mathrm{~h}, 4 \text { weeks } \\
90 \text { days } \\
3,7,28 \text { days } \\
8 \text { weeks (once a week) } \\
1,3,10,30 \text { days }\end{array}$ & $\begin{array}{l}{[58]} \\
{[59]} \\
{[60]} \\
{[61]} \\
{[40]}\end{array}$ \\
\hline & & $18 \mathrm{~Gy}$ & Single & $30,60,90$ days & [62] \\
\hline & SLG & $10 \mathrm{~Gy}$ & Single & $1,3,7,14$ days & [63] \\
\hline & \multirow{2}{*}{ PG, SMG } & $5 \mathrm{~Gy}$ & Single & $1,2,3,4,5,30,60,90$ days & [64] \\
\hline & & 15 Gy & Single & $\begin{array}{l}4 \mathrm{~h}, 8 \text { weeks } \\
30,65 \text { days }\end{array}$ & $\begin{array}{l}{[45]} \\
{[65]}\end{array}$ \\
\hline & \multirow{2}{*}{ PG, SMG, SLG } & $5 \mathrm{~Gy}$ & Single & $9,30,60,90$ days & {$[66]$} \\
\hline & & $15 \mathrm{~Gy}$ & Single & $10,30,60,120$ days & [43] \\
\hline \multirow{13}{*}{ Rat } & \multirow{3}{*}{ PG } & 15 Gy & Single & 7 days & [30] \\
\hline & & $20 \mathrm{~Gy}$ & Single & 1 days & [67] \\
\hline & & $30,40 \mathrm{~Gy}$ & Fraction $(6$ or 8 Gy $\times 5$ days $)$ & 180 days & [35] \\
\hline & \multirow{5}{*}{ SMG } & $7.5 \mathrm{~Gy}$ & Single & 14 days & [68] \\
\hline & & $15 \mathrm{~Gy}$ & Single & 3,30 days & [41] \\
\hline & & $18 \mathrm{~Gy}$ & Single & $\begin{array}{l}4,7,28 \text {, and } 56 \text { days } \\
8,16, \text { and } 24 \text { weeks }\end{array}$ & $\begin{array}{l}{[69]} \\
{[70]}\end{array}$ \\
\hline & & $20 \mathrm{~Gy}$ & Single & 7 days & [71] \\
\hline & & 75 Gy & $\begin{array}{c}\text { Fraction }(15 \mathrm{~Gy} \times 5) \text { every second } \\
\text { week }\end{array}$ & 6 weeks & [72] \\
\hline & \multirow{3}{*}{ PG, SMG } & $\begin{array}{c}2.5,5,7.5,10,15 \\
\text { Gy }\end{array}$ & Single & $3,6,9,12$ months & [36] \\
\hline & & $15 \mathrm{~Gy}$ & Single & 2 months & [37] \\
\hline & & $20,35,45 \mathrm{~Gy}$ & Fraction ( 4 or 7 or $9 \mathrm{~Gy} \times 5$ days) & $2,4,10,180$ days & [34] \\
\hline & \multirow{2}{*}{ PG, SMG, SLG } & $15 \mathrm{~Gy}$ & Single & 3,70 days & [73] \\
\hline & & $18 \mathrm{~Gy}$ & Single & $2,6,8$, or 12 weeks & [44] \\
\hline \multirow[b]{2}{*}{ Minipig } & PG & $37.5 \mathrm{~Gy}$ & Fraction $(7.5$ Gy $\times 5$ days $)$ & 12 weeks & [32] \\
\hline & PG, SMG & 70 Gy & $\begin{array}{c}\text { Fraction }(2 \mathrm{~Gy} \times 35) \text { daily, except } \\
\text { weekends }\end{array}$ & 1 month & [23] \\
\hline Monkey & PG, SMG & $\begin{array}{l}50,55 \mathrm{~Gy}, \\
\text { CHART }\end{array}$ & $\begin{array}{c}50 \text { Gy in } 20 \text { fraction } \\
55 \text { Gy in } 25 \text { fraction } \\
\text { CHART }\end{array}$ & 16 weeks (fortnightly) & [22] \\
\hline Rabbits & PG, SMG & $10,20,30,40 \mathrm{~Gy}$ & Fraction $(2 \mathrm{~Gy} \times 5,10,15,20$ days $)$ & immediately & [31] \\
\hline
\end{tabular}

PG, parotid gland; SMG, submandibular gland; SLG, sublingual gland; CHART, continuous hyperfractionated accelerated radiotherapy.

In both rats and mice, the ductal obstruction was known to cause apoptosis of acinar cells and the proliferation of duct cells $[82,87,88]$. An excessive increase in the intrasalivary pressure acted as the physical trauma on acinar cells, consequently leading to cellular death, whereas ductal cells remained grossly intact but with ductal dilation $[89,90]$. A previous study showed that the apoptotic reaction occurred throughout the acinar cells several days after the obstruction, and the apoptotic cells were then phagocytized by the adjacent acinar cells or intraepithelial macrophages [88]. After 7 days, 
most acinar cells had disappeared, leaving prominent residual ducts [88]. Another study in the rat reported that the rapid, progressive cellular loss of greater than $85 \%$ within the acinar tissue accounted for glandular shrinkage within two weeks after ductal obstruction [91].

Although multiple mechanisms are involved in the apoptotic response and subsequent secretory dysfunction after ductal obstruction, several mechanisms might be related to the disturbance in membrane receptors and signaling pathway of acinar cells. A previous study revealed up-regulation of the mitogen-activated protein kinases, extracellular signal-regulated receptor kinase $1 / 2$, and p38 during the atrophic and regeneration phases of ductal obstruction/release [92]. Another study showed that P2Y increased about 15-fold three days after obstruction, and this increase returned to the control level by 14 days after removal of the obstruction [93]. The expression level of AQP5 after ligation was also decreased with the localization at the apical membranes of the remained acinar cells [94].

In addition, a previous study showed the apoptotic reaction in ductal cells, the marked shortage of intercalated ducts, and the dilation of ductal and acinar lumens [82,95]. It also reported that the observed apoptosis of the capillary endothelial cells was related to the reduction in the capillary bed [82]. Other studies demonstrated that the expression of Bcl-2 was increased in the ductal cells after the ductal obstruction [77].

Previous studies also showed that after ductal obstruction, myoepithelial cells underwent both apoptotic and proliferative reaction, leading primarily to changes in the distribution and morphology rather than rapid disappearance [96-98]. Furthermore, it was also shown that myoepithelial cells seldom participated in the regeneration of atrophied glands, despite their proliferation and differentiation [82,98].

With regard to the repair process, studies have shown that the histomorphology of the gland returned to almost normal after duct recanalization $[24,79,81]$. Acinar cell recovery was considered to involve redifferentiation from the remaining cells [79]. A recent study showed that the duct and acinar cell lineages were maintained separately, even after indirect mechanical injury such as obstruction [20]. However, others studies suggested the possible involvement of cellular plasticity between the residual ductal and acinar populations during salivary regeneration $[78,95]$ (Table 3). 
Table 3. Obstruction protocols in previous studies.

\begin{tabular}{|c|c|c|c|c|c|c|c|}
\hline \multirow{2}{*}{ Animal } & \multirow{2}{*}{ Target Gland } & \multicolumn{3}{|c|}{ Obstruction Protocol } & \multicolumn{2}{|c|}{ Duration } & \multirow{2}{*}{ Ref. } \\
\hline & & Material & Method & Control & Obstruction & Deobstruction & \\
\hline \multirow{6}{*}{ Mice } & SMG (unilateral) & 6-0 Ethicon suture & & Normal & $3,5,7$ days & - & [99] \\
\hline & SMG (unilateral) & $\begin{array}{l}\text { Metal Sugita titanium } \\
\text { aneurysm clip }\end{array}$ & & Normal & 7 days & $0,1,3,7,14$ days & [78] \\
\hline & SMG (unilateral) & Silk thread & & Normal & 8 weeks & - & [76] \\
\hline & SMG (unilateral) & Surgical sutures & & Contralateral & $0,1,3,6,12,24 \mathrm{~h}, 1,3,6$ days & - & [94] \\
\hline & SMG (unilateral) & $\begin{array}{l}\text { Sugita titanium aneurysm } \\
\text { clip }\end{array}$ & & Contralateral & 2 months & 1 week, 1,2 months & [84] \\
\hline & SMG (unilateral) & Surgical sutures & & Contralateral & 7 days & 28 day & [85] \\
\hline \multirow{23}{*}{ Rat } & PG (bilateral) & 3-0 silk ligature & & Sham & 7 days & 7,30 days & [92] \\
\hline & PG & Suture & & Normal & $1,7,15,21,30,60$ days & - & [100] \\
\hline & PG (unilateral) & Clip & & Sham & 14 days & $2,8,14,21,25,28$ days & [101] \\
\hline & PG (unilateral) & Liu et al. 1998 & & & 2 weeks & 1,2 weeks & [91] \\
\hline & PG (unilateral) & Ligaclips, double clipped & & Sham & 7 days & $0,1,2,3,4,5,7,10,14$ days & [79] \\
\hline & PG (unilateral) & Metal clips, double clipped & & Normal & 7 days & $0,1,3,5,7,10,12,14,17,21$ days & [102] \\
\hline & PG (unilateral) & 4-0 silk, double ligated & & Normal & $\begin{array}{c}12,18 \mathrm{~h} / 1,2,3,4,5,7 \\
\text { days/2,3,4,8,12,24 weeks }\end{array}$ & - & [82] \\
\hline & SMG (unilateral) & Surgical sutures & $7 \mathrm{~mm}$ distal to the gland hilum & Contralateral & 3 days & $3,7,14,21$ days & [93] \\
\hline & SMG (unilateral) & Metal clip & & Contralateral & 1 day & 3 days & [24] \\
\hline & SMG (unilateral) & Metal clip & & Contralateral & 4 weeks & 8 weeks & [83] \\
\hline & SMG (unilateral) & Metal microclip & $5 \mathrm{~mm}$ posterior to the ductal orifice & Contralateral & 1 day & - & [75] \\
\hline & SMG+SLG & Metal clip & & Normal & 2 weeks & 3 days & [81] \\
\hline & SMG+SLG & Metal clip & & Normal & 2 weeks & $3,5,7$ days, 8 weeks & [103] \\
\hline & SMG & $3-0 / 8-0$ silk sutures & Midportion/the orifice of the duct & Normal & $1,3,5,7$ days & - & [104] \\
\hline & SMG (unilateral) & - & & Normal & $1,3,7,14,21$ days & - & [105] \\
\hline & SMG (unilateral) & $\begin{array}{l}\text { Surgical vascular ligation } \\
\text { clip }\end{array}$ & $5 \mathrm{~mm}$ distal to the glandular porta & Contralateral & $1,3,7$ days & 1,2 weeks & [106] \\
\hline & SMG & $8-0$ suture & & Sham & 2,3,4 weeks & - & [17] \\
\hline & SMG (unilateral) & Metal microclip & $5 \mathrm{~mm}$ posterior to the ductal orifice & Contralateral & $1,4,8$ weeks & $8,16,24$ weeks & [11] \\
\hline & SMG (bilateral) & Metal clip & Near the hilum & Normal & 7 days & $0,1,3,5,7,11$ days & [80] \\
\hline & SMG (bilateral) & Metal clip & & Normal & 7 days & $0,3,7,14$ days & [107] \\
\hline & SMG (unilateral) & Metal clip, double ligation & & Normal & $1,2,3,4,5,7,(10), 14,(21), 28$ days & - & {$[88,96]$} \\
\hline & SMG(unilateral) & Metal clip, double ligation & Near the hilum of the gland & Normal & 7 days & $0,1,2,3,4,5,7,10,14$ days & {$[108,109]$} \\
\hline & SMG (unilateral) & Ligaclips, double ligation & Near the hilum of the gland & Normal & $1,3,5,10,14$ days & - & {$[110,111]$} \\
\hline
\end{tabular}


Table 3. Cont.

\begin{tabular}{|c|c|c|c|c|c|c|c|}
\hline \multirow{2}{*}{ Animal } & \multirow{2}{*}{ Target Gland } & \multicolumn{3}{|c|}{ Obstruction Protocol } & \multicolumn{2}{|c|}{ Duration } & \multirow{2}{*}{ Ref. } \\
\hline & & Material & Method & Control & Obstruction & Deobstruction & \\
\hline & $\begin{array}{l}\text { SMG, SLG } \\
\text { (bilateral) }\end{array}$ & - & At a distance of $2 \mathrm{~mm}$ from the organs & Sham & 2 weeks & - & [112] \\
\hline & $\begin{array}{l}\text { SMG(+SLG) } \\
\text { (unilateral) }\end{array}$ & Metal microclip & $\begin{array}{l}\text { less than } 5 \mathrm{~mm} \text { posterior to the ductal } \\
\text { orifice/less than } 5 \mathrm{~mm} \text { anterior to the hilum of } \\
\text { the gland }\end{array}$ & Contralateral & $1,2,7,14,21$ days & - & [86] \\
\hline & $\begin{array}{l}\text { SMG (+SLG) } \\
\text { (unilateral) }\end{array}$ & Metal microclip & $5 \mathrm{~mm}$ posterior to the ductal orifice & Normal & $1,3,5,7,9,14$ days & - & [113] \\
\hline & $\begin{array}{l}\text { SMG, SLG } \\
\text { (unilateral) }\end{array}$ & Metal clips, double ligation & Near the hilum of the gland & Normal & $1,3,5,7,10,14,28$ days & - & [114] \\
\hline & SLG (unilateral) & Metal clip, double ligation & Near the hilum of the SLG & Normal & $1,3,5,7,10,14,28$ days & & [97] \\
\hline & SLG (unilateral) & $\begin{array}{l}\text { Metal clip/ligaclips, double } \\
\text { ligation }\end{array}$ & Near the hilum of the SLG & Normal & 7 days & $0,1,2,3,4,5,7,10,14$ days & {$[98,115]$} \\
\hline \multirow{2}{*}{ Cat } & PG (unilateral) & $3-0$ silk sutures & & Contralateral & From 1 to 365 days & - & [21] \\
\hline & $\begin{array}{l}\text { PG, SMG, SLG } \\
\text { (unilateral) }\end{array}$ & $3 / 0$ braided silk & & Contralateral & From 1 to 365 days & - & [116] \\
\hline \multirow{2}{*}{ Rabbit } & PG (bilateral) & $3-0$ silk suture & & Sham & $1,7,14,30,60$ days & - & [95] \\
\hline & SMG & 6-0 nylon thread & At $5 \mathrm{~mm}$ behind the orifice of the duct & & $2,4,8$ weeks & - & [117] \\
\hline
\end{tabular}

PG, parotid gland; SMG, submandibular gland; SLG, sublingual gland; CHART, continuous hyperfractionated accelerated radiotherapy. 


\section{Discussion}

The development of a new conceptual therapy for the regeneration of the salivary gland has long been required. Although histocellular information is essential to fully understand the various pathologic conditions of salivary dysfunctions, histological evaluation is not clinically available for salivary glands in most patients. This is because, although frequent sialopathies underlying salivary dysfunctions are not a life-threatening condition, biopsy is an invasive procedure, possibly causing complications such as infection, poor wound healing, fistula, and scar formation. Therefore, it is insufficient to establish the histocellular knowledge through biopsy in humans [9]. Recently, animal models mimicking diseases/conditions have been developed to study the functional alteration of salivary glands $[6,20]$. The experimental application of an animal model could allow for the examination of histomorphological and physiological information as well as facilitate the development of therapeutic strategies by reproducing various salivary pathologic conditions. However, there are some considerations to note in current animal models of salivary disorders. Radiation experiments in animals have been used as a good model for identifying the sequential reaction of the salivary gland after radiotherapy. Most studies using the animal model have reported a decrease in salivation rate and gland weight and loss of acinar cells [29,34-36]. However, some studies have reported conflicting results, showing little inflammation, cell apoptosis, and acinar cell loss after irradiation [57]. The main difference in radiation animal studies is the amount of radiation required for a significant loss of salivary gland functionality. For a more precise analysis, it is necessary to prove the optimal irradiation-induced salivary gland disorder after radiotherapy. In addition to most of the irradiated animal models were produced in a manner that is dissimilar to the actual human radiation therapy. Recently relatively large animals, such as monkeys and mini-pigs, have been used to mimic salivary gland dysfunction of humans [22,23,32]. The animals can be utilized as a more feasible biological model for studying salivary gland dysfunction because the salivary glands of valuable large animals are anatomically and physiologically similar to human glands [22,23,32]. However, researchers should be aware that physiological differences in salivary function among species can cause bias in animal modeling as shown in Table 4. Furthermore, in the ductal obstruction model, the optimal obstruction period has not been determined because of the diverse atrophic or apoptotic alterations according to the given periods, although most studies maintained the ductal obstruction for one or two weeks $[17,95]$. These variations are partly explained by the technical diversity in ligation $[95,116]$. Some researchers have indicated that the application of single ductal ligation with a surgical suture might fail to obtain complete blockage of duct, thereby escaping some acinar cells from apoptotic conditions even after prolonged obstruction [88]. Furthermore, an early study reported that, despite the application of the same ductal obstructive procedure, the severity of the atrophic reaction varied widely [116]. In addition, Sjögren's syndrome is a systemic autoimmune disease that affects the salivary gland. Recent studies have highlighted the impact of the depletion of stem cells as a factor contributing to the loss of gland regeneration [118]. However, the development of treatments for the salivary gland disorder of Sjögren's syndrome has been hindered by insufficient animal models that can completely reproduce the human condition. 
Table 4. Histopathological change in animal model system of salivary gland dysfunction.

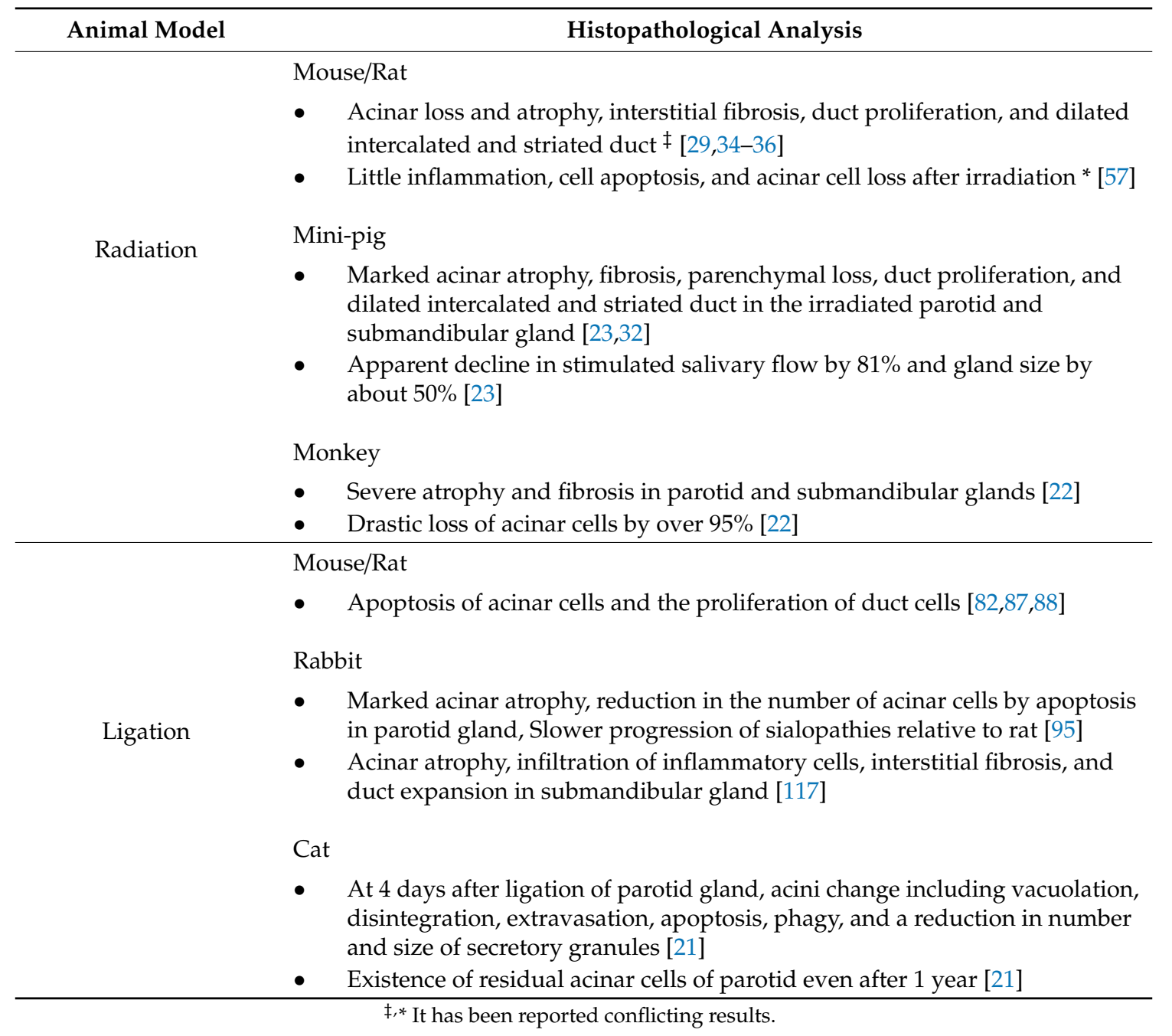

Recently, researchers have attempted to implement novel therapeutic strategies, such as stem cell or gene therapy, delivery of bioactive compound, and bioengineering approaches for the functional regeneration of salivary glands [119]. Appropriate therapeutic strategies should be applied depending on the cause of the salivary gland disorder. Salivary gland disorders in the radiation model are characterized by cell damage and fibrosis [6]. The Sjögren's syndrome model is characterized by the destruction of inflammatory tissue and consequent depletion of stem cells in the salivary gland [118]. With aging, salivary glands are shown to undergo histomorphological changes and functional alterations, such as the reduction of salivation and increase in apoptotic epithelial cells [120]. Therefore, treatment of salivary gland disorders should be individualized for each patient according to the causes of cell damage and pattern of tissue alteration. The most appropriate and effective treatment should be provided for the functional regeneration of the salivary gland, such as stem cell transplantation, bioactive compound or gene delivery to damaged cells, or bioengineering approach. However, the therapeutic options have been mostly applicated in a radiation-induced xerostomia model. Very little research has been performed in the animal models of ligation-induced salivary gland damage or Sjögren's syndrome. In addition, many studies have used an irradiated submandibular gland to examine the functional regeneration of the salivary gland [119]. Potential therapeutic strategies should be applied and analyzed in various animal models of salivary gland dysfunction. An accurate understanding of the molecular mechanism involved the in functional regeneration of salivary glands 
will be needed to restore salivary function lost as a consequence of side effects of radiotherapy, various diseases, or mechanical injuries affecting the salivary glands.

Table 5. Comparative anatomical and histological findings of major salivary glands.

\begin{tabular}{|c|c|c|}
\hline & Human & Rodent \\
\hline \multirow[t]{2}{*}{ Parotid } & $\begin{array}{l}\text { - } \quad \text { Main composition with serous acini } \\
\text { - } \quad \text { Prominent striated and intercalated ducts } \\
\text { - } \quad \text { Prominent intralobular adipose tissue }\end{array}$ & $\begin{array}{l}\text { - Main composition with serous acini } \\
\text { Prominent striated and intercalated ducts } \\
\text { - } \quad \text { Less prominent intralobular adipose tissue * }\end{array}$ \\
\hline & $\begin{array}{l}\text { - } \quad \text { Location-anteroinferior area of ear } \\
\text { - } \quad \text { Size-1st largest }\end{array}$ & $\begin{array}{l}\text { - Location-posteroinferior area of ear * } \\
\text { - Size-2nd largest* }\end{array}$ \\
\hline \multirow[t]{2}{*}{ Submandi-bular } & $\begin{array}{l}\text { Mixed composition with both serous and } \\
\text { mucous acini } \\
\text { - } \quad \text { Marked demilunes } \\
\text { interceveloped striated and } \\
\text { interaled ducts }\end{array}$ & $\begin{array}{ll}\text { - } & \text { Mixed composition with predominant } \\
\text { - } & \text { Less/no marked demilunes * } \\
\text { - } & \text { Well-developed striated and } \\
\text { intercalated ducts } \\
\text { - } \\
\begin{array}{l}\text { Prominent granular convoluted tubule } \\
\text { producing various growth factors * }\end{array}\end{array}$ \\
\hline & $\begin{array}{l}\text { - Location-submandibular area } \\
\text { - } \quad \text { Size-2nd largest }\end{array}$ & $\begin{array}{l}\text { - Location-ventral cervical area * } \\
\text { - Size-1st largest * }\end{array}$ \\
\hline \multirow[t]{2}{*}{ Sublingual } & - Mostly comprised of mucous acini & - $\quad$ Mostly comprised of mucous acini \\
\hline & $\begin{array}{ll}\text { - } & \text { Location-sublingual area } \\
\text { - } & \text { Size-smallest } \\
\end{array}$ & $\begin{array}{l}\text { - } \quad \text { Location-ventral cervical area * } \\
\text { - } \quad \text { Size-smallest }\end{array}$ \\
\hline
\end{tabular}

* The asterisk denotes the anatomical and histological difference.

Among experimental animals, murine models are regarded as excellent candidate due to not only their histomorphological similarities with humans, but also experimental conveniences [121,122]. However, questions remain regarding whether the results of studies in murine models could produce the same results in humans. Since murine salivary glands used in animal experiments showed a similar, but different, anatomical physiology compared with humans (Table 5), it is important to consider that no single animal model system has covered all aspects of the pathogenesis and clinical features of each pathological condition. For this reason, various protocols using animal models have been applied to recapitulate clinical pathologies as much as possible. In particular, establishing and applying an animal model that more precisely resembles and mimics the human pathologic conditions is fundamental. These proper animal model systems would be an opportune chance to promote our understanding of destructive and reparative mechanisms under physiological and pathological conditions. Furthermore, existing and future animal model systems will provide the fundamental evidence to justify progressive experiments as preclinical steps. In the future, accumulated findings will facilitate the ability of clinicians to provide permanent and not merely palliative treatment.

Author Contributions: Conceptualization: J.-Y.K. (Ji-Youn Kim) and J.-K.J.; writing-original draft preparation: J.-Y.K. (Ji-Youn Kim) and J.-K.J.; writing_review and editing: J.-Y.K. (Ji-Youn Kim), C.-H.A., J.-Y.K. (Jae-Young Kim), and J.-K.J.; visualization: J.-Y.K. (Ji-Youn Kim) and J.-K.J.; supervision: C.-H.A. and J.-Y.K. (Jae-Young Kim); funding acquisition: J.-K.J. All authors have read and agreed to the published version of the manuscript.

Funding: This work was supported by a grant from the National Research Foundation of Korea (NRF) funded by the Korean government (grant no. NRF-2019R1I1A3A01062091).

Conflicts of Interest: The authors declare no conflict of interest. 


\section{Abbreviations}

$\begin{array}{ll}\text { PG } & \text { Parotid gland } \\ \text { SMG } & \text { Submandibular gland } \\ \text { SLG } & \text { Sublingual gland } \\ \text { AQP5 } & \text { Acuaporin 5 } \\ \text { SOCE } & \text { Store-operated Ca2+ entry }\end{array}$

\section{References}

1. Kamrani, P.; Pillarisetty, L.S. Anatomy, Bony Pelvis and Lower Limb, Toe Nails; StatPearls Publishing LLC.: Treasure Island, FL, USA, 2020.

2. de Almeida, P.D.V.; Grégio, A.M.; Machado, M.A.; de Lima, A.A.; Azevedo, L.R. Saliva Composition and Functions: A Comprehensive Review. J. Contemp. Dent. Pract. 2008, 9, 72-80.

3. Dawes, C.; Pedersen, A.M.; Villa, A.; Ekström, J.; Proctor, G.B.; Vissink, A.; Aframian, D.; McGowan, R.; Aliko, A.; Narayana, N. The Functions of Human Saliva: A Review Sponsored by the World Workshop on Oral Medicine VI. Arch. Oral Biol. 2015, 60, 863-874. [CrossRef] [PubMed]

4. Ghannam, M.G.; Singh, P. Anatomy, Head and Neck, Salivary Glands. In StatPearls; Anonymous; StatPearls Publishing LLC: Treasure Island, FL, USA, 2020.

5. Gupta, S.; Ahuja, N. Salivary Glands. In Histology; Heinbockel, T., Shields, V.D.C., Eds.; IntechOpen: London, UK, 2019.

6. Lombaert, I.; Movahednia, M.M.; Adine, C.; Ferreira, J.N. Concise Review: Salivary Gland Regeneration: Therapeutic Approaches from Stem Cells to Tissue Organoids. Stem Cells 2017, 35, 97-105. [CrossRef] [PubMed]

7. Miranda-Rius, J.; Brunet-Llobet, L.; Lahor-Soler, E.; Farré, M. Salivary Secretory Disorders, Inducing Drugs, and Clinical Management. Int. J. Med. Sci. 2015, 12, 811-824. [CrossRef] [PubMed]

8. Krishnamurthy, S.; Vasudeva, S.B.; Vijayasarathy, S. Salivary Gland Disorders: A Comprehensive Review. World J. Stomatol. 2015, 4, 56-71. [CrossRef]

9. Cheng, S.C.; Wu, V.W.; Kwong, D.L.; Ying, M.T. Assessment of Post-Radiotherapy Salivary Glands. Br. J. Radiol. 2011, 84, 393-402. [CrossRef] [PubMed]

10. Nam, K.; Dean, S.M.; Brown, C.T.; Smith, R.J., Jr.; Lei, P.; Andreadis, S.T.; Baker, O.J. Synergistic Effects of Laminin-1 Peptides, VEGF and FGF9 on Salivary Gland Regeneration. Acta Biomater. 2019, 91, 186-194. [CrossRef]

11. Osailan, S.M.; Proctor, G.B.; Carpenter, G.H.; Paterson, K.L.; McGurk, M. Recovery of Rat Submandibular Salivary Gland Function Following Removal of Obstruction: A Sialometrical and Sialochemical Study. Int. J. Exp. Pathol. 2006, 87, 411-423. [CrossRef]

12. Seferos, N.; Daskala, I.; Kotsiou, A.; Tsamouri, M.; Tesseromatis, C. Nifedipine-Induced Histological Changes in the Parotid Glands of Hypertensive Rats. Braz. Oral Res. 2014, 28. [CrossRef]

13. Torun, N.; Muratli, A.; Serim, B.D.; Ergulen, A.; Altun, G.D. Radioprotective Effects of Amifostine, L-Carnitine and Vitamin E in Preventing Early Salivary Gland Injury Due to Radioactive Iodine Treatment. Curr. Med. Imaging Rev. 2019, 15, 395-404. [CrossRef]

14. Yao, C.; Purwanti, N.; Karabasil, M.R.; Azlina, A.; Javkhlan, P.; Hasegawa, T.; Akamatsu, T.; Hosoi, T.; Ozawa, K.; Hosoi, K. Potential Down-Regulation of Salivary Gland AQP5 by LPS via Cross-Coupling of NF-KappaB and P-C-Jun/C-Fos. Am. J. Pathol. 2010, 177, 724-734. [CrossRef] [PubMed]

15. Lavoie, T.N.; Lee, B.H.; Nguyen, C.Q. Current Concepts: Mouse Models of Sjogren's Syndrome. J. Biomed. Biotechnol. 2011, 2011, 549107. [CrossRef] [PubMed]

16. Nam, K.; Maruyama, C.L.; Wang, C.S.; Trump, B.G.; Lei, P.; Andreadis, S.T.; Baker, O.J. Laminin-111-Derived Peptide Conjugated Fibrin Hydrogel Restores Salivary Gland Function. PLoS ONE 2017, 12, e0187069. [CrossRef] [PubMed]

17. Okazaki, Y.; Kagami, H.; Hattori, T.; Hishida, S.; Shigetomi, T.; Ueda, M. Acceleration of Rat Salivary Gland Tissue Repair by Basic Fibroblast Growth Factor. Arch. Oral Biol. 2000, 45, 911-919. [CrossRef]

18. Romero, A.C.; Bergamaschi, C.T.; de Souza, D.N.; Nogueira, F.N. Salivary Alterations in Rats with Experimental Chronic Kidney Disease. PLoS ONE 2016, 11, e0148742. [CrossRef]

19. Sadic, M.; Demirel, K.; Halacli, S.O.; Karakok, E.; Koca, G.; Ekinci, O.; Demircan, K.; Korkmaz, M. Expression of ADAMTS2 and ADAMTS5 in the Salivary Gland of Rats After Radioiodine Therapy. Nucl. Med. Commun. 2018, 39, 110-117. [CrossRef] 
20. Weng, P.L.; Aure, M.H.; Maruyama, T.; Ovitt, C.E. Limited Regeneration of Adult Salivary Glands After Severe Injury Involves Cellular Plasticity. Cell Rep. 2018, 24, 1464-1470.e3. [CrossRef]

21. Harrison, J.D.; Fouad, H.M.; Garrett, J.R. The Effects of Ductal Obstruction on the Acinar Cells of the Parotid of Cat. Arch. Oral Biol. 2000, 45, 945-949. [CrossRef]

22. Price, R.E.; Ang, K.K.; Stephens, L.C.; Peters, L.J. Effects of Continuous Hyperfractionated Accelerated and Conventionally Fractionated Radiotherapy on the Parotid and Submandibular Salivary Glands of Rhesus Monkeys. Radiother. Oncol. 1995, 34, 39-46. [CrossRef]

23. Radfar, L.; Sirois, D.A. Structural and Functional Injury in Minipig Salivary Glands Following Fractionated Exposure to 70 Gy of Ionizing Radiation: An Animal Model for Human Radiation-Induced Salivary Gland Injury. Oral Surg. Oral Med. Oral Pathol. Oral Radiol. Endod. 2003, 96, 267-274. [CrossRef]

24. Carpenter, G.H.; Osailan, S.M.; Correia, P.; Paterson, K.P.; Proctor, G.B. Rat Salivary Gland Ligation Causes Reversible Secretory Hypofunction. Acta Physiol. 2007, 189, 241-249. [CrossRef] [PubMed]

25. Anderson, L.C. Salivary Gland Structure and Function in Experimental Diabetes Mellitus. Biomed. Rev. 1998, 9, 107-119. [CrossRef]

26. Wang, S.; Marchal, F.; Zou, Z.; Zhou, J.; Qi, S. Classification and Management of Chronic Sialadenitis of the Parotid Gland. J. Oral Rehabil. 2009, 36, 2-8. [CrossRef] [PubMed]

27. Bray, F.; Ferlay, J.; Soerjomataram, I.; Siegel, R.L.; Torre, L.A.; Jemal, A. Global Cancer Statistics 2018: GLOBOCAN Estimates of Incidence and Mortality Worldwide for 36 Cancers in 185 Countries. CA Cancer J. Clin. 2018, 68, 394-424. [CrossRef]

28. Grundmann, O.; Mitchell, G.C.; Limesand, K.H. Sensitivity of Salivary Glands to Radiation: From Animal Models to Therapies. J. Dent. Res. 2009, 88, 894-903. [CrossRef] [PubMed]

29. Avila, J.L.; Grundmann, O.; Burd, R.; Limesand, K.H. Radiation-Induced Salivary Gland Dysfunction Results from p53-Dependent Apoptosis. Int. J. Radiat. Oncol. Biol. Phys. 2009, 73, 523-529. [CrossRef]

30. Konak, M.; Cincik, H.; Erkul, E.; Kucukodaci, Z.; Gungor, A.; Ozdemir, S.; Cekin, E.; Arisan, V.; Mutluoglu, M.; Salihoglu, M. The Protective Effects of Different Treatments on Rat Salivary Glands After Radiotherapy. Eur. Arch. Otorhinolaryngol. 2016, 273, 4501-4506. [CrossRef]

31. Kujan, O.; Othman, R.; Alshehri, M.; Iqbal, F.; Kochaji, N. Proliferative Activity of Myoepithelial Cells in Irradiated Rabbit Parotid and Submandibular Salivary Glands. J. Int. Oral Health 2015, 7, 1-5.

32. Zhu, Z.; Pang, B.; Iglesias-Bartolome, R.; Wu, X.; Hu, L.; Zhang, C.; Wang, J.; Gutkind, J.S.; Wang, S. Prevention of Irradiation-Induced Salivary Hypofunction by Rapamycin in Swine Parotid Glands. Oncotarget 2016, 7 , 20271-20281. [CrossRef]

33. Wu, V.W.C.; Leung, K.Y. A Review on the Assessment of Radiation Induced Salivary Gland Damage After Radiotherapy. Front. Oncol. 2019, 9, 1090. [CrossRef]

34. Henriksson, R.; Fröjd, O.; Gustafsson, H.; Johansson, S.; Yi-Qing, C.; Franzén, L.; Bjermer, L. Increase in Mast Cells and Hyaluronic Acid Correlates to Radiation-Induced Damage and Loss of Serous Acinar Cells in Salivary Glands: The Parotid and Submandibular Glands Differ in Radiation Sensitivity. Br. J. Cancer 1994, 69, 320-326. [CrossRef] [PubMed]

35. Grehn, A.L.; Gustafsson, H.; Franzén, L.; Thornell, L.E.; Henriksson, R. Ultrastructural Morphometry of Parotid Acinar Cells Following Fractionated Irradiation. Oral Oncol. 1997, 33, 23-28. [CrossRef]

36. Nagler, R.M.; Baum, B.J.; Miller, G.; Fox, P.C. Long-Term Salivary Effects of Single-Dose Head and Neck Irradiation in the Rat. Arch. Oral Biol. 1998, 43, 297-303. [CrossRef]

37. Nagler, R.; Marmary, Y.; Golan, E.; Chevion, M. Novel Protection Strategy Against X-Ray-Induced Damage to Salivary Glands. Radiat. Res. 1998, 149, 271-276. [CrossRef] [PubMed]

38. Humphries, M.J.; Limesand, K.H.; Schneider, J.C.; Nakayama, K.I.; Anderson, S.M.; Reyland, M.E. Suppression of Apoptosis in the Protein Kinase Cdelta Null Mouse In Vivo. J. Biol. Chem. 2006, 281, 9728-9737. [CrossRef] [PubMed]

39. Konings, A.W.; Coppes, R.P.; Vissink, A. On the Mechanism of Salivary Gland Radiosensitivity. Int. J. Radiat. Oncol. Biol. Phys. 2005, 62, 1187-1194. [CrossRef]

40. Liu, X.; Gong, B.; de Souza, L.B.; Ong, H.L.; Subedi, K.P.; Cheng, K.T.; Swaim, W.; Zheng, C.; Mori, Y.; Ambudkar, I.S. Radiation Inhibits Salivary Gland Function by Promoting STIM1 Cleavage by Caspase-3 and Loss of SOCE Through a TRPM2-Dependent Pathway. Sci. Signal. 2017, 10. [CrossRef] 
41. Li, Z.; Zhao, D.; Gong, B.; Xu, Y.; Sun, H.; Yang, B.; Zhao, X. Decreased Saliva Secretion and Down-Regulation of AQP5 in Submandibular Gland in Irradiated Rats. Radiat. Res. 2006, 165, 678-687. [CrossRef]

42. Ambudkar, I. Calcium Signaling Defects Underlying Salivary Gland Dysfunction. Biochim. Biophys. Acta Mol. Cell Res. 2018, 1865, 1771-1777. [CrossRef]

43. Liu, X.; Cotrim, A.; Teos, L.; Zheng, C.; Swaim, W.; Mitchell, J.; Mori, Y.; Ambudkar, I. Loss of TRPM2 Function Protects Against Irradiation-Induced Salivary Gland Dysfunction. Nat. Commun. 2013, 4, 1515. [CrossRef]

44. Kim, J.H.; Jeong, B.K.; Jang, S.J.; Yun, J.W.; Jung, M.H.; Kang, K.M.; Kim, T.G.; Woo, S.H. Alpha-Lipoic Acid Ameliorates Radiation-Induced Salivary Gland Injury by Preserving Parasympathetic Innervation in Rats. Int. J. Mol. Sci. 2020, 21, 2260. [CrossRef] [PubMed]

45. Mizrachi, A.; Cotrim, A.P.; Katabi, N.; Mitchell, J.B.; Verheij, M.; Haimovitz-Friedman, A. Radiation-Induced Microvascular Injury as a Mechanism of Salivary Gland Hypofunction and Potential Target for Radioprotectors. Radiat. Res. 2016, 186, 189-195. [CrossRef] [PubMed]

46. Sholley, M.M.; Sodicoff, M.; Pratt, N.E. Early Radiation Injury in the Rat Parotid Gland. Reaction of Acinar Cells and Vascular Endothelium. Lab. Investig. J. Tech. Methods Pathol. 1974, 31, 340-354.

47. Aure, M.H.; Konieczny, S.F.; Ovitt, C.E. Salivary Gland Homeostasis Is Maintained Through Acinar Cell Self-Duplication. Dev. Cell 2015, 33, 231-237. [CrossRef]

48. Aure, M.H.; Arany, S.; Ovitt, C.E. Salivary Glands: Stem Cells, Self-Duplication, or Both? J. Dent. Res. 2015, 94, 1502-1507. [CrossRef]

49. Kwak, M.; Alston, N.; Ghazizadeh, S. Identification of Stem Cells in the Secretory Complex of Salivary Glands. J. Dent. Res. 2016, 95, 776-783. [CrossRef]

50. Meyer, S.; Chibly, A.M.; Burd, R.; Limesand, K.H. Insulin-Like Growth Factor-1-Mediated DNA Repair in Irradiated Salivary Glands Is Sirtuin-1 Dependent. J. Dent. Res. 2017, 96, 225-232. [CrossRef]

51. Nguyen, V.T.; Dawson, P.; Zhang, Q.; Harris, Z.; Limesand, K.H. Administration of Growth Factors Promotes Salisphere Formation from Irradiated Parotid Salivary Glands. PLoS ONE 2018, 13, e0193942. [CrossRef]

52. Wong, W.Y.; Allie, S.; Limesand, K.H. PKCzeta and JNK Signaling Regulate Radiation-Induced Compensatory Proliferation in Parotid Salivary Glands. PLoS ONE 2019, 14, e0219572. [CrossRef]

53. Limesand, K.H.; Schwertfeger, K.L.; Anderson, S.M. MDM2 Is Required for Suppression of Apoptosis by Activated Akt1 in Salivary Acinar Cells. Mol. Cell. Biol. 2006, 26, 8840-8856. [CrossRef]

54. Gilman, K.E.; Camden, J.M.; Klein, R.R.; Zhang, Q.; Weisman, G.A.; Limesand, K.H. P2X7 Receptor Deletion Suppresses Gamma-Radiation-Induced Hyposalivation. Am. J. Physiol. Regul. Integr. Comp. Physiol. 2019, 316, R687-R696. [CrossRef] [PubMed]

55. May, A.J.; Cruz-Pacheco, N.; Emmerson, E.; Gaylord, E.A.; Seidel, K.; Nathan, S.; Muench, M.O.; Klein, O.D.; Knox, S.M. Diverse Progenitor Cells Preserve Salivary Gland Ductal Architecture After Radiation-Induced Damage. Development 2018, 145. [CrossRef] [PubMed]

56. Takashi, I.; Sumita, Y.; Yoshida, T.; Honma, R.; Iwatake, M.; Raudales, J.L.M.; Shizuno, T.; Kuroshima, S.; Masuda, H.; Seki, M.; et al. Anti-Inflammatory and Vasculogenic Conditioning of Peripheral Blood Mononuclear Cells Reinforces Their Therapeutic Potential for Radiation-Injured Salivary Glands. Stem Cell Res. Ther. 2019, 10, 304.

57. Marmary, Y.; Adar, R.; Gaska, S.; Wygoda, A.; Maly, A.; Cohen, J.; Eliashar, R.; Mizrachi, L.; Orfaig-Geva, C.; Baum, B.J.; et al. Radiation-Induced Loss of Salivary Gland Function Is Driven by Cellular Senescence and Prevented by IL6 Modulation. Cancer Res. 2016, 76, 1170-1180. [CrossRef] [PubMed]

58. Xu, L.; Yang, X.; Chen, J.; Ge, X.; Qin, Q.; Zhu, H.; Zhang, C.; Sun, X. Simvastatin Attenuates Radiation-Induced Salivary Gland Dysfunction in Mice. Drug Des. Dev. Ther. 2016, 10, 2271-2278.

59. Lombaert, I.M.; Brunsting, J.F.; Wierenga, P.K.; Kampinga, H.H.; de Haan, G.; Coppes, R.P. Cytokine Treatment Improves Parenchymal and Vascular Damage of Salivary Glands After Irradiation. Clin. Cancer Res. 2008, 14, 7741-7750. [CrossRef]

60. Zeidan, Y.H.; Xiao, N.; Cao, H.; Kong, C.; Le, Q.T.; Sirjani, D. Botulinum Toxin Confers Radioprotection in Murine Salivary Glands. Int. J. Radiat. Oncol. Biol. Phys. 2016, 94, 1190-1197. [CrossRef]

61. Takahashi, A.; Inoue, H.; Mishima, K.; Ide, F.; Nakayama, R.; Hasaka, A.; Ryo, K.; Ito, Y.; Sakurai, T.; Hasegawa, Y.; et al. Evaluation of the Effects of Quercetin on Damaged Salivary Secretion. PLoS ONE 2015, 10, e0116008. [CrossRef] 
62. Zhang, J.; Cui, L.; Xu, M.; Zheng, Y. Restoring the Secretory Function of Irradiation-Damaged Salivary Gland by Administrating Deferoxamine in Mice. PLoS ONE 2014, 9, e113721. [CrossRef]

63. Emmerson, E.; May, A.J.; Berthoin, L.; Cruz-Pacheco, N.; Nathan, S.; Mattingly, A.J.; Chang, J.L.; Ryan, W.R.; Tward, A.D.; Knox, S.M. Salivary Glands Regenerate After Radiation Injury Through SOX2-Mediated Secretory Cell Replacement. EMBO Mol. Med. 2018, 10, e8051. [CrossRef]

64. Morgan-Bathke, M.; Harris, Z.I.; Arnett, D.G.; Klein, R.R.; Burd, R.; Ann, D.K.; Limesand, K.H. The Rapalogue, CCI-779, Improves Salivary Gland Function Following Radiation. PLoS ONE 2014, 9, e113183. [CrossRef] [PubMed]

65. Taniguchi, A.; Susa, T.; Kogo, H.; Iizuka-Kogo, A.; Yokoo, S.; Matsuzaki, T. Long-Term Pilocarpine Treatment Improves Salivary Flow in Irradiated Mice. Acta Histochem. Cytochem. 2019, 52, 45-58. [CrossRef] [PubMed]

66. Grundmann, O.; Fillinger, J.L.; Victory, K.R.; Burd, R.; Limesand, K.H. Restoration of Radiation Therapy-Induced Salivary Gland Dysfunction in Mice by Post Therapy IGF-1 Administration. BMC Cancer 2010, 10, 417. [CrossRef] [PubMed]

67. Lopez-Jornet, P.; Gómez-García, F.; García Carrillo, N.; Valle-Rodríguez, E.; Xerafin, A.; Vicente-Ortega, V. Radioprotective Effects of Lycopene and Curcumin During Local Irradiation of Parotid Glands in Sprague Dawley Rats. Br. J. Oral Maxillofac. Surg. 2016, 54, 275-279. [CrossRef] [PubMed]

68. Araujo, M.V.T.; Spadella, M.A.; Chies, A.B.; Arruda, G.V.; Santos, T.M.; Cavariani, M.M.; Domeniconi, R.F. Effect of Low Radiation Dose on the Expression and Location of Aquaporins in Rat Submandibular Gland. Tissue Cell 2018, 53, 104-110. [CrossRef] [PubMed]

69. Kim, J.H.; Kim, K.M.; Jung, M.H.; Jung, J.H.; Kang, K.M.; Jeong, B.K.; Kim, J.P.; Park, J.J.; Woo, S.H. Protective Effects of Alpha Lipoic Acid on Radiation-Induced Salivary Gland Injury in Rats. Oncotarget 2016, 7, 29143-29153. [CrossRef]

70. Xiong, X.; Shi, X.; Chen, F. Human Adipose Tissue-derived Stem Cells Alleviate Radiation-induced Xerostomia. Int. J. Mol. Med. 2014, 34, 749-755. [CrossRef]

71. Xiang, B.; Han, L.; Wang, X.; Tang, L.; Li, K.; Li, X.; Zhao, X.; Xia, M.; Zhou, X.; Zhang, F.; et al. Nicotinamide Phosphoribosyltransferase Upregulation by Phenylephrine Reduces Radiation Injury in Submandibular Gland. Int. J. Radiat. Oncol. Biol. Phys. 2016, 96, 538-546. [CrossRef]

72. Sonstevold, T.; Johannessen, A.C.; Stuhr, L. A Rat Model of Radiation Injury in the Mandibular Area. Rad. Oncol. 2015, 10, 129. [CrossRef]

73. Abedi, S.M.; Yarmand, F.; Motallebnejad, M.; Seyedmajidi, M.; Moslemi, D.; Bijani, A.; Hosseinimehr, S.J. Radioprotective Effect of Thymol Against Salivary Glands Dysfunction Induced by Ionizing Radiation in Rats. Iran. J. Pharm. Res. 2016, 15, 861-866.

74. Frith, C.H.; Townsend, J.W. Histology and Ultrastructure, Salivary Glands, Mouse. In Digestive System. Monographs on Pathology of Laboratory Animals; Jones, T.C., Popp, J.A., Mohr, U., Eds.; Springer: Berlin/Heidelberg, Germany, 1997; pp. 223-230.

75. Correia, P.N.; Carpenter, G.H.; Osailan, S.M.; Paterson, K.L.; Proctor, G.B. Acute Salivary Gland Hypofunction in the Duct Ligation Model in the Absence of Inflammation. Oral Dis. 2008, 14, 520-528. [CrossRef] [PubMed]

76. Ohno, K.; Hattori, T.; Kagami, H.; Ueda, M. Effects of Preceding Sialadenitis on the Development of Autoimmunity Against Salivary Gland. Oral Dis. 2007, 13, 158-162. [CrossRef] [PubMed]

77. Zuo, J.H.; Sun, C.H.; Gao, H.; Wang, L.F.; Zhu, Y.H. Role of Bcl-2 and Bax in Parotid Gland Atrophy. Eur. Rev. Med. Pharmacol. Sci. 2017, 21, 5315-5320. [PubMed]

78. Nagai, K.; Arai, H.; Okudera, M.; Yamamura, T.; Oki, H.; Komiyama, K. Epiregulin Is Critical for the Acinar Cell Regeneration of the Submandibular Gland in a Mouse Duct Ligation Model. J. Oral Pathol. Med. 2014, 43, 378-387. [CrossRef]

79. Takahashi, S.; Schoch, E.; Walker, N.I. Origin of Acinar Cell Regeneration After Atrophy of the Rat Parotid Induced by Duct Obstruction. Int. J. Exp. Pathol. 1998, 79, 293-301. [CrossRef]

80. Ueda, K.; Shimizu, O.; Oka, S.; Saito, M.; Hide, M.; Matsumoto, M. Distribution of Tenascin-C, Fibronectin and Collagen Types III and IV During Regeneration of Rat Submandibular Gland. Int. J. Oral Maxillofac. Surg. 2009, 38, 79-84. [CrossRef]

81. Cotroneo, E.; Proctor, G.B.; Paterson, K.L.; Carpenter, G.H. Early Markers of Regeneration Following Ductal Ligation in Rat Submandibular Gland. Cell Tissue Res. 2008, 332, 227-235. [CrossRef] 
82. Walker, N.I.; Gobé, G.C. Cell Death and Cell Proliferation During Atrophy of the Rat Parotid Gland Induced by Duct Obstruction. J. Pathol. 1987, 153, 333-344. [CrossRef]

83. Carpenter, G.H.; Khosravani, N.; Ekström, J.; Osailan, S.M.; Paterson, K.P.; Proctor, G.B. Altered Plasticity of the Parasympathetic Innervation in the Recovering Rat Submandibular Gland Following Extensive Atrophy. Exp. Physiol. 2009, 94, 213-219. [CrossRef]

84. Watanabe, H.; Takahashi, H.; Hata-Kawakami, M.; Tanaka, A. Expression of C-Kit and Cytokeratin 5 in the Submandibular Gland After Release of Long-Term Ligation of the Main Excretory Duct in Mice. Acta Histochem. Cytochem. 2017, 50, 111-118. [CrossRef]

85. Woods, L.T.; Camden, J.M.; El-Sayed, F.G.; Khalafalla, M.G.; Petris, M.J.; Erb, L.; Weisman, G.A. Increased Expression of TGF-Beta Signaling Components in a Mouse Model of Fibrosis Induced by Submandibular Gland Duct Ligation. PLoS ONE 2015, 10, e0123641. [CrossRef] [PubMed]

86. Osailan, S.M.; Proctor, G.B.; McGurk, M.; Paterson, K.L. Intraoral Duct Ligation Without Inclusion of the Parasympathetic Nerve Supply Induces Rat Submandibular Gland Atrophy. Int. J. Exp. Pathol. 2006, 87, 41-48. [CrossRef] [PubMed]

87. Hisatomi, Y.; Okumura, K.; Nakamura, K.; Matsumoto, S.; Satoh, A.; Nagano, K.; Yamamoto, T.; Endo, F. Flow Cytometric Isolation of Endodermal Progenitors from Mouse Salivary Gland Differentiate into Hepatic and Pancreatic Lineages. Hepatology 2004, 39, 667-675. [CrossRef] [PubMed]

88. Takahashi, S.; Nakamura, S.; Suzuki, R.; Islam, N.; Domon, T.; Yamamoto, T.; Wakita, M. Apoptosis and Mitosis of Parenchymal Cells in the Duct-Ligated Rat Submandibular Gland. Tissue Cell 2000, 32, 457-463. [CrossRef]

89. Bhaskar, S.N.; Bolden, T.E.; Weinmann, J.P. Experimental Obstructive Adenitis in the Mouse. J. Dent. Res. 1956, 35, 852-862. [CrossRef] [PubMed]

90. Harrison, J.D.; Garrett, J.R. The Effects of Ductal Ligation on the Parenchyma of Salivary Glands of Cat Studied by Enzyme Histochemical Methods. Histochem. J. 1976, 8, 35-44. [CrossRef] [PubMed]

91. Scott, J.; Liu, P.; Smith, P.M. Morphological and Functional Characteristics of Acinar Atrophy and Recovery in the Duct-Ligated Parotid Gland of the Rat. J. Dent. Res. 1999, 78, 1711-1719. [CrossRef]

92. Dang, H.; Elliott, J.J.; Lin, A.L.; Zhu, B.; Katz, M.S.; Yeh, C.K. Mitogen-Activated Protein Kinase Up-Regulation and Activation During Rat Parotid Gland Atrophy and Regeneration: Role of Epidermal Growth Factor and Beta 2-Adrenergic Receptors. Differ. Res. Biol. Divers. 2008, 76, 546-557. [CrossRef]

93. Ahn, J.S.; Camden, J.M.; Schrader, A.M.; Redman, R.S.; Turner, J.T. Reversible Regulation of P2Y(2) Nucleotide Receptor Expression in the Duct-Ligated Rat Submandibular Gland. Am. J. Physiol. Cell Physiol. 2000, 279, C286-C294. [CrossRef]

94. Purwanti, N.; Karabasil, M.R.; Matsuo, S.; Chen, G.; Javkhlan, P.; Azlina, A.; Hasegawa, T.; Yao, C.; Akamatsu, T.; Hosoi, K. Induction of Sca-1 via Activation of STAT3 System in the Duct Cells of the Mouse Submandibular Gland by Ligation of the Main Excretory Duct. Am. J. Physiol. Gastrointest. Liver Physiol. 2011, 301, G814-G824. [CrossRef]

95. Maria, O.M.; Maria, S.M.; Redman, R.S.; Maria, A.M.; Saad El-Din, T.A.; Soussa, E.F.; Tran, S.D. Effects of Double Ligation of Stensen's Duct on the Rabbit Parotid Gland. Biotech. Histochem. 2014, 89, 181-198. [CrossRef] [PubMed]

96. Takahashi, S.; Nakamura, S.; Shinzato, K.; Domon, T.; Yamamoto, T.; Wakita, M. Apoptosis and Proliferation of Myoepithelial Cells in Atrophic Rat Submandibular Glands. J. Histochem. Cytochem. 2001, 49, 1557-1564. [CrossRef] [PubMed]

97. Takahashi, S.; Shinzato, K.; Domon, T.; Yamamoto, T.; Wakita, M. Proliferation and Distribution of Myoepithelial Cells During Atrophy of the Rat Sublingual Gland. J. Oral Pathol. Med. 2003, 32, 90-94. [CrossRef] [PubMed]

98. Takahashi, S.; Kohgo, T.; Nakamura, S.; Arambawatta, A.K.; Domon, T.; Yamamoto, T.; Wakita, M. Biological Behavior of Myoepithelial Cells in the Regeneration of Rat Atrophied Sublingual Glands Following Release from Duct Ligation. J. Mol. Histol. 2005, 36, 373-379. [CrossRef] [PubMed]

99. Bozorgi, S.S.; Proctor, G.B.; Carpenter, G.H. Rapamycin Delays Salivary Gland Atrophy Following Ductal Ligation. Cell Death Dis. 2014, 5, e1146. [CrossRef] [PubMed] 
100. Miguel, M.C.; Andrade, E.S.; Taga, R.; Pinto, L.P.; Souza, L.B. Hyperplasia of Myoepithelial Cells Expressing Calponin During Atrophy of the Rat Parotid Gland Induced by Duct Ligation. Histochem. J. 2002, 34, 499-506. [CrossRef]

101. Miyazaki, T.; Tatsukawa, S.; Kitamura, H.; Ina, K.; Abe, H.; Fujikura, Y. Morphological and Functional Changes of the Rat Parotid Glandular Cells by Clipping and Reopening the Parotid Duct, Using HAM8 Antibody. Anat. Sci. Int. 2008, 83, 89-95. [CrossRef]

102. Takahashi, S.; Nakamura, S.; Suzuki, R.; Domon, T.; Yamamoto, T.; Wakita, M. Changing Myoepithelial Cell Distribution During Regeneration of Rat Parotid Glands. Int. J. Exp. Pathol. 1999, 80, 283-290. [CrossRef]

103. Cotroneo, E.; Proctor, G.B.; Carpenter, G.H. Regeneration of Acinar Cells Following Ligation of Rat Submandibular Gland Retraces the Embryonic-Perinatal Pathway of Cytodifferentiation. Differ. Res. Biol. Divers. 2010, 79, 120-130. [CrossRef]

104. Hishida, S.; Ozaki, N.; Honda, T.; Shigetomi, T.; Ueda, M.; Hibi, H.; Sugiura, Y. Atrophy of Submandibular Gland by the Duct Ligation and a Blockade of SP Receptor in Rats. Nagoya J. Med. Sci. 2016, 78, 215-227.

105. Jung, J.; Cho, J.G.; Chae, S.W.; Lee, H.M.; Hwang, S.J.; Woo, J.S. Epithelial Na+ Channel (ENaC) Expression in Obstructive Sialadenitis of the Submandibular Gland. Arch. Oral Biol. 2011, 56, 121-126. [CrossRef] [PubMed]

106. Mizobe, K.; Kawabe, Y.; Bando, Y.; Sakiyama, K.; Araki, H.; Amano, O. Localization of hsp27 in the Rat Submandibular Gland Following the Application of Various Surgical Treatments. Acta Histochem. Cytochem. 2014, 47, 255-264. [CrossRef] [PubMed]

107. Yasumitsu, T.; Shimizu, O.; Shiratsuchi, H.; Miyake, Y.; Yonehara, Y. Distribution of Aquaporin-5, Transforming Growth Factor-Beta1 and Laminin During Regeneration of Atrophic Rat Submandibular Glands After Duct Ligation. J. Oral Sci. 2018, 60, 595-600. [CrossRef]

108. Takahashi, S.; Shinzato, K.; Nakamura, S.; Domon, T.; Yamamoto, T.; Wakita, M. Cell Death and Cell Proliferation in the Regeneration of Atrophied Rat Submandibular Glands After Duct Ligation. J. Oral Pathol. Med. 2004, 33, 23-29. [CrossRef] [PubMed]

109. Takahashi, S.; Shinzato, K.; Domon, T.; Yamamoto, T.; Wakita, M. Mitotic Proliferation of Myoepithelial Cells During Regeneration of Atrophied Rat Submandibular Glands After Duct Ligation. J. Oral Pathol. Med. 2004, 33, 430-434. [CrossRef]

110. Takahashi, S.; Gobe, G.C.; Yoshimura, Y.; Kohgo, T.; Yamamoto, T.; Wakita, M. Participation of the Fas and Fas Ligand Systems in Apoptosis During Atrophy of the Rat Submandibular Glands. Int. J. Exp. Pathol. 2007, 88, 9-17. [CrossRef]

111. Takahashi, S.; Yoshimura, Y.; Yamamoto, T.; Wakita, M. Cellular Expression of Bcl-2 and Bax in Atrophic Submandibular Glands of Rats. Int. J. Exp. Pathol. 2008, 89, 303-308. [CrossRef]

112. Kurahashi, M. The Effect of Dietary Consistency and Water Content on the Parotid Glands of Submandibular and Sublingual Duct-Ligated Rats. Arch. Oral Biol. 2002, 47, 369-374. [CrossRef]

113. Silver, N.; Proctor, G.B.; Arno, M.; Carpenter, G.H. Activation of mTOR Coincides with Autophagy During Ligation-Induced Atrophy in the Rat Submandibular Gland. Cell Death Dis. 2010, 1, e14. [CrossRef]

114. Takahashi, S.; Shinzato, K.; Nakamura, S.; Domon, T.; Yamamoto, T.; Wakita, M. The Roles of Apoptosis and Mitosis in Atrophy of the Rat Sublingual Gland. Tissue Cell 2002, 34, 297-304. [CrossRef]

115. Takahashi, S.; Nakamura, S.; Domon, T.; Yamamoto, T.; Wakita, M. Active Participation of Apoptosis and Mitosis in Sublingual Gland Regeneration of the Rat Following Release from Duct Ligation. J. Mol. Histol. 2005, 36, 199-205. [CrossRef] [PubMed]

116. Harrison, J.D.; Garrett, J.R. Histological Effects of Ductal Ligation of Salivary Glands of the Cat. J. Pathol. 1976, 118, 245-254. [CrossRef] [PubMed]

117. Li, W.; Wei, L.; Wang, F.; Peng, S.; Cheng, Y.; Li, B. An Experimental Chronic Obstructive Sialadenitis Model by Partial Ligation of the Submandibular Duct Characterised by Sialography, Histology, and Transmission Electron Microscopy. J. Oral Rehabil. 2018, 45, 983-989. [CrossRef] [PubMed]

118. Pringle, S.; Wang, X.; Verstappen, G.M.P.J.; Terpstra, J.H.; Zhang, C.K.; He, A.; Patel, V.; Jones, R.E.; Baird, D.M.; Spijkervet, F.K.L.; et al. Gland Stem Cells Age Prematurely in Primary Sjogren's Syndrome. Arthritis Rheumatol. 2019, 71, 133-142. [CrossRef] [PubMed]

119. Rocchi, C.; Emmerson, E. Mouth-Watering Results: Clinical Need, Current Approaches, and Future Directions for Salivary Gland Regeneration. Trends Mol. Med. 2020, 26, 649-669. [CrossRef] [PubMed]

120. Choi, J.S.; Park, I.S.; Kim, S.K.; Lim, J.Y.; Kim, Y.M. Analysis of Age-Related Changes in the Functional Morphologies of Salivary Glands in Mice. Arch. Oral Biol. 2013, 58, 1635-1642. [CrossRef] 
121. Amano, O.; Mizobe, K.; Bando, Y.; Sakiyama, K. Anatomy and histology of rodent and human major salivary glands: -overview of the Japan salivary gland society-sponsored workshop-. Acta Histochem Cytochem. 2012, 45, 241-250. [CrossRef]

122. Maruyama, C.L.; Monroe, M.M.; Hunt, J.P.; Buchmann, L.; Baker, O.J. Comparing human and mouse salivary glands: A practice guide for salivary researchers. Oral Dis. 2019, 25, 403-415. [CrossRef]

Publisher's Note: MDPI stays neutral with regard to jurisdictional claims in published maps and institutional affiliations.

(C) 2020 by the authors. Licensee MDPI, Basel, Switzerland. This article is an open access article distributed under the terms and conditions of the Creative Commons Attribution (CC BY) license (http://creativecommons.org/licenses/by/4.0/). 